\title{
CURRENT POPULATION STATUS OF A LOCALLY ENDEMIC SPRINGSNAIL (HYDROBIIDAE: PYRGULOPSIS BEDFORDENSIS) IN MONTANA
}

\author{
David M. Stagliano 1,2
}

\begin{abstract}
Aвstract.-The Bedford springsnail (Pyrgulopsis bedfordensis) is one of only 2 species of the genus Pyrgulopsis discovered east of the northern Continental Divide and appears restricted to one spring in central Montana. Due to its endemism, this species was placed on the Montana Species of Concern list as S1, critically imperiled. Despite the snail's rarity, nothing was known of this population's characteristics; it was last sampled in 1999. In 2015, I quantitatively sampled this population using a Hess sampler $(n=3)$ over a 40-m reach to determine the snail's benthic density and describe the associated macroinvertebrate community. Average densities of the springsnail were 30,540 live individuals per $\mathrm{m}^{2}$ (SE 2625) and 17,353 empty shells per $\mathrm{m}^{2}$ (SE 1389). Other benthic macroinvertebrates collected with the springsnail (11 taxa [SE 1.5]) were comparatively low in abundance, averaging 1533 individuals per $\mathrm{m}^{2}$ (SE 274). The Bedford springsnail population density at this Montana site ranks among one of the highest reported among its conspecifics.

RESUMEN.-En 2015, probé descubierto recientemente (2001) la población del caracol Pyrgulopsis bedfordensis primavera, en el centro de Montana para estimaciones de densidad bénticos. El Bedford Spring caracol es sólo una de las dos especies de este género, descubrió al este de la divisoria continental septentrional y aparece restringido a esta primavera. Debido a la naturaleza endémica de esta especie, fue colocada en el Montana Especies de Preocupación lista como S1, críticamente en peligro. A pesar de la rareza del caracol, nada se sabe de las características de esta población; la última vez que se muestrean en 1999. Yo cuantitativamente esta población muestreada utilizando un Muestreador Hess $(n=3)$ a través de un alcance de 40 metros para determinar los caracoles bénticos y densidad de la comunidad de macroinvertebrados asociados. Las densidades medias de springsnail fueron 30,540 individuos vivos por $\mathrm{m}^{2}(\mathrm{SE} 2625)$ y 17,353 proyectiles vacíos por $\mathrm{m}^{2}$ (SE 1389). Otros macroinvertebrados bénticos recolectados con la springsnail, 11 taxones (SE 1.5), eran comparativamente bajos en abundancia, con un promedio de 1533 personas por $\mathrm{m}^{2}$ (SE 274). El Bedford springsnail la densidad de la población en este sitio se encuentra entre una de las más altas reportadas.
\end{abstract}

The Gastropoda snail family Hydrobiidae is a species-rich and highly endemic group (Kabat and Hershler 1993, Hershler 1994). Within this family, the genus Pyrgulopsis contains the most species in North America. In 2014, Hershler et al. (2014) recognized 137 species, and new species have been added within the last decade (Hershler and Gustafson 2001, Hershler et al. 2008, 2013). The presumed extirpation of numerous unnamed springsnail species in the western United States has already occurred due to the hydrologic modification and degradation of spring habitats (Frest and Johannes 1995, USFWS 2003, Hershler et al. 2014). The recently described Pyrgulopsis bedfordensis, Bedford springsnail (Hershler and Gustafson 2001 ), is only one of 2 species of this genus discovered east of the northern Continental Divide in Montana and Idaho (Hershler et al. 2008). The Bedford springsnail presently occupies approximately $2 \mathrm{~km}$ of Bedford
Spring Creek, which enters a private pond and then flows $300 \mathrm{~m}$ downstream of the pond into Canyon Ferry Lake, a reservoir on the Missouri River (Fig. 1). Bedford springsnails were collected at this site in 1991, 1995, and 1999 (Hershler and Gustafson 2001) and have not been sampled since. Due to this restricted distribution, this endemic species was given a conservation status rank of G1 (Globally Rare) and placed on the Montana Species of Concern list as S1, critically imperiled (MTNHP 2015, Nature Serve 2015). The goal of this study was to quantitatively sample the Bedford springsnail population in order to document the species' continued presence, estimate benthic density, and describe the associated macroinvertebrate community.

The single-thread-channel sample reach begins $30 \mathrm{~m}$ upstream from U.S. Hwy. 287 (46.36279, -111.55298); approximately $1 \mathrm{~km}$ downstream from the type locality reported by Hershler and Gustafson (2001) (Fig. 1). I

${ }^{1}$ Montana Natural Heritage Program, 1515 E. Sixth Ave., Box 201800 Helena, MT 59620-1800.

2Present address: Montana Biological Survey, 1901 Peosta Ave, Helena, MT 59601. E-mail: dstagliano88@gmail.com 


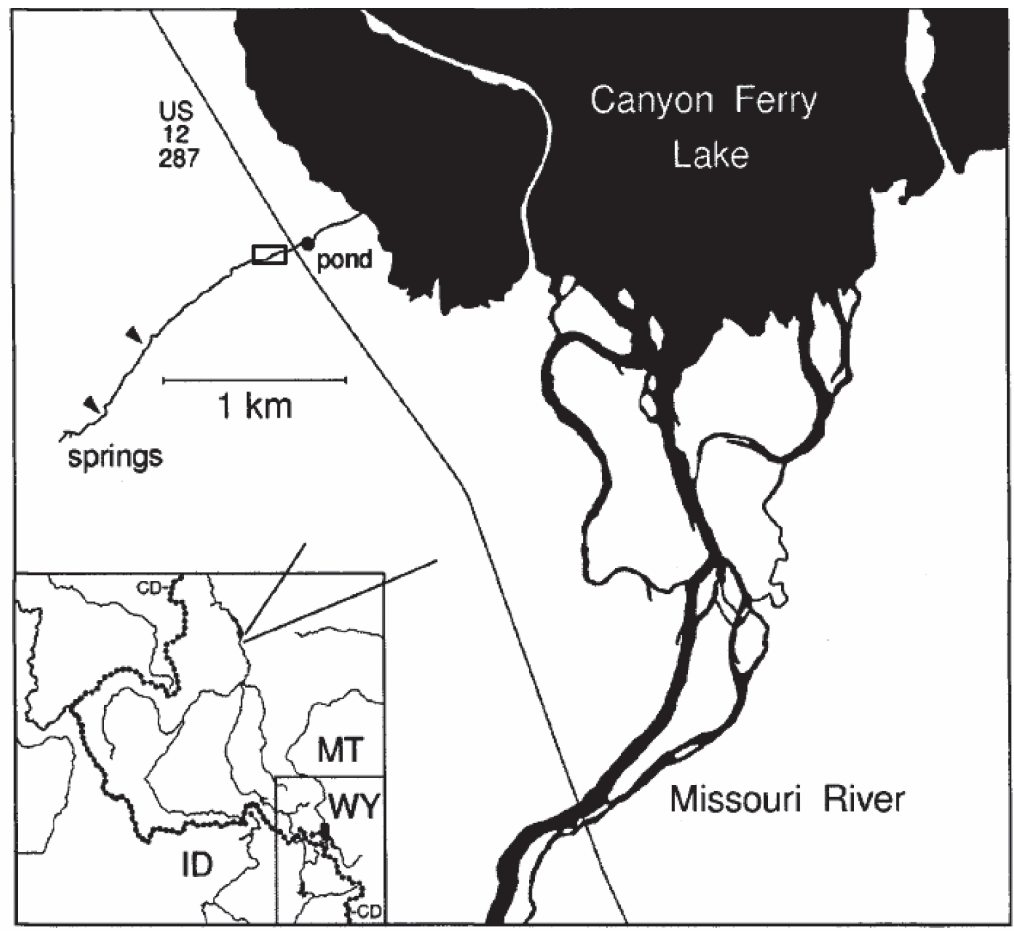

Fig. 1. Map showing location of Warm Springs Creek. The box outlines this study reach, while arrows identify type locality sampling sites. (Map reprinted with permission from publisher Allen Press, Lawrence, Kansas, and authors Hershler and Gustafson. (c) 2001. Proceedings of the Biological Society of Washington 114.1).

measured the wetted stream width at 10 transects along the 40-m reach and visually estimated benthic substrates according to Wolman (1954) size classes. On 22 July 2015, I collected quantitative benthic samples using a Hess sampler $(33 \mathrm{~cm}$ diameter, $500 \mu \mathrm{m}$ mesh) at 3 locations along a $40-\mathrm{m}$ reach. Each Hess sample represents a benthic area of $0.1 \mathrm{~m}^{2}$. At each sampling point, the Hess sampler was pushed into the stream bottom to form an effective seal, and all cobbles $(>64 \mathrm{~mm})$ within the sampling frame were scrubbed clean of organisms and removed; then the entire area within the sampler frame was raked (disturbed) for approximately $1 \mathrm{~min}$ until all organic matter and macroinvertebrates were washed into the collection net of the Hess sampler. Collection contents were deposited onto a $500-\mu \mathrm{m}$ sieve and transferred into 1-L sample jars filled with $95 \%$ ethanol. Samples were brought back to the Stag Benthics Laboratory in Helena, Montana, and processed entirely. Macroinvertebrates picked from the samples were identified to the genus/species taxonomic level with a dissecting microscope $(40 \times$ to $100 \times)$ using standardized protocols and taxonomic references (MDEQ 2012). Voucher specimens have been deposited in the invertebrate collections of the Orma J. Smith Museum of Natural History, College of Idaho (Caldwell, ID) and the Montana Natural Heritage Program Voucher Series (Helena, MT).

The Bedford spring stream reach sampled in this survey flows through a moderately shaded (about 30\%), open-riparian forest with green ash (Fraxinus pennsylvanica), boxelder (Acer negundo) and Russian olive (Elaeagnus angustifolia) overstory and a dense riparian forb (field mint, Mentha arvensis; wild parsnip, Pastinaca sp.; Willow-herb, Epilobium sp.; field sowthistle, Sonchus arvensis) understory. Aquatic plants in and along the wetted channel were dominated by watercress (Rorippa sp.).

This study confirms that the Bedford springsnail population in Montana is viable and robust with an average benthic density of 30,540 live individuals per $\mathrm{m}^{2}$ (SE 2625) 
TABLE 1. Pyrgulopsis bedfordensis and other macroinvertbrate densities (individuals per $\mathrm{m}^{2}$ ) recorded in the study reach. $\mathrm{SE}=$ standard error of the mean.

\begin{tabular}{|c|c|c|c|c|c|c|c|}
\hline Class/order & Family & Taxon & Hess 1 & Hess 2 & Hess 3 & Average & SE \\
\hline Gastropoda & Hydrobiidae & $\begin{array}{l}\text { Pyrgulopsis } \\
\text { bedfordensis }\end{array}$ & 26,240 & 35,300 & 30,080 & 30,540 & 2625 \\
\hline Gastropoda & Hydrobiidae & $\begin{array}{l}\text { Pyrgulopsis } \\
\text { dead shells }\end{array}$ & 15,120 & 19,900 & 17,040 & 17,353 & 1389 \\
\hline Coleoptera & Elmidae & Microcylloepus & 20 & 0 & 20 & 13.3 & 7 \\
\hline Lepidoptera & Crambidae & Petrophila & 20 & 40 & 40 & 33.3 & 7 \\
\hline Crustacea & Dogielinotidae & Hyalella & 20 & 0 & 20 & 13.3 & 7 \\
\hline Gastropoda & Lymnaeidae & Fossaria humilis & 20 & 0 & 0 & 6.7 & 7 \\
\hline Annelida & Lumbricidae & Lumbricidae & 240 & 200 & 280 & 240.0 & 23 \\
\hline Annelida & Tubificidae & Tubificidae & 60 & 20 & 20 & 33.3 & 13 \\
\hline Turbellaria ${ }^{a}$ & Turbellaria ${ }^{\mathrm{a}}$ & Turbellaria $^{\mathrm{a}}$ & 40 & 20 & 20 & 26.7 & 7 \\
\hline Odonata & Gomphidae & $\begin{array}{l}\text { Ophiogomphus } \\
\text { severus }\end{array}$ & 20 & 20 & 0 & 13.3 & 7 \\
\hline Trichoptera & Glossosomatidae & Protoptila & 20 & 0 & 20 & 13.3 & 7 \\
\hline Trichoptera & Hydropsychidae & $\begin{array}{l}\text { Hydropsyche } \\
\text { occidentalis }\end{array}$ & 420 & 120 & 280 & 273.3 & 87 \\
\hline Trichoptera & Hydroptilidae & Ochrotrichia & 20 & 0 & 20 & 13.3 & 7 \\
\hline Trichoptera & Leptoceridae & Nectopsyche & 1100 & 780 & 540 & 807 & 162 \\
\hline \multirow{3}{*}{ Trichoptera } & Philopotamidae & Chimarra utahensis & 80 & 20 & 40 & 46.7 & 18 \\
\hline & & $\begin{array}{l}\text { Invertebrates } \\
\quad \text { (non-Pyrgulopsis) }\end{array}$ & 2060 & 1220 & 1280 & 1520.0 & 271 \\
\hline & & Total taxon richness & 14 & 9 & 12 & 11.7 & 1.5 \\
\hline
\end{tabular}

aTurbellaria is a traditional subdivision of the phylum Platyhelminthes (flatworms).

(Table 1). Empty snail shells contributed a large proportion of the benthic individuals, averaging 17,353 empty shells per $\mathrm{m}^{2}$ (SE 1389) (Table 1). All springsnail age classes were represented in the live individuals, from single whorl to 5-whorl shell heights, whereas empty shells were dominated by individuals that contained 3-5 teleoconch whorls. Benthic macroinvertebrates collected with the snails averaged 1520 individuals per $\mathrm{m}^{2}$ (SE 271) and consisted of 11 taxa per sample (SE 1.5) (Table 1). Cumulative taxon richness for the 3 samples was 13 taxa (Table 1). Caddisfly species $(n=5)$ dominated the other macroinvertebrates collected in the samples and composed up to $75 \%$ of the numbers of non-springsnail individuals (Table 1). One other native snail species, Fossaria humilis (Lymnaeidae), cooccurred at very low numbers (average 6.7 individuals per $\mathrm{m}^{2}$ ) with the springsnails.

At the time of our survey (09:30 MST), air temperature was $18.5{ }^{\circ} \mathrm{C}$, water temperature $21.9^{\circ} \mathrm{C}$, specific conductivity $405 \mu \mathrm{S}$, and $\mathrm{pH}$ 7.4. The water temperature reported at the spring outflow in August 1999 was $23.0{ }^{\circ} \mathrm{C}$ (Hershler and Gustafson 2001); our site about $1 \mathrm{~km}$ downstream cooled approximately $1{ }^{\circ} \mathrm{C}$ from the source. Maximum depth in the reach was $40 \mathrm{~cm}$, and average wetted width was $0.4 \mathrm{~m}(0.25-1.2 \mathrm{~m})$. The geomorphology of the 40-m reach was riffle/run with benthic substrate dominated by gravels and pebbles $(8-64 \mathrm{~mm})$ $(75 \%)$, with cobbles $(>64 \mathrm{~mm})$ in the thalweg $(15 \%)$ and silted depositional areas (10\%).

This study confirms the continued presence and viability of this endemic species, as well as providing an initial population estimate. The Bedford springsnail is restricted to approximately $2 \mathrm{~km}$ of this spring creek and has no possibility of expansion upstream or downstream into suitable habitat. Other springsnail conspecifics are restricted to much smaller distances from the spring source $(5-300 \mathrm{~m})$ due to changing abiotic factors (Mladenka and Minshall 2001, Malcom et al. 2005, Tsai et al. 2007). During summer 2012, the private pond that is fed by the spring was drained and subsequently dried out, likely killing any springsnails inhabiting this habitat (DMS personal observation). Average Bedford springsnail densities reported at this site $\left(30,500\right.$ per $\left.\mathrm{m}^{2}\right)$ are higher than some populations reported (average 10,000 per $\mathrm{m}^{2}$ [Mladenka and Minshall 2001] or $<6000$ per $\mathrm{m}^{2}$ [Martinez and Thome 2006]), but not as dense as about 56,000 per $\mathrm{m}^{2}$ reported for the San Bernardino springsnail (Malcom et al. 2005). If we extrapolate the average snail density calculated from the Hess data by the average suitable benthic habitat area (about $900 \mathrm{~m}^{2}$ ), 
there are approximately 27.5 million snails in this population.

Other benthic macroinvertebrates collected in the Hess samples $(n=13$ total taxa) were comparatively lower in diversity than reported by Hershler and Gustafson (2001) $(n=31$ species). But, those researchers did not report the sampling method used for the invertebrate collections, other than sweeping an aerial dip-net along the aquatic vegetation or picking snails off the substrates. The Hess samples collected in this study focused on pebble/gravel substrates in water $<25 \mathrm{~cm}$ deep. I did not attempt to sample woody debris or depositional areas with aquatic vegetation, which are microhabitats that may have yielded additional species. Martinez and Thome (2006) reported that pebble/gravel substrate was preferred habitat of the Page springsnail, Pyrgulopsis morrisoni, with significantly higher densities than found on sand or silt. We report 4 invertebrate taxa in common with the Hershler and Gustafson (2001) study: Microcylloepus, Fossaria humilis, Chimarra utahensis, and Protoptila. Microcylloepus is a genus of common riffle beetles that occur in springs, and Montana has an endemic species, M. browni, which is restricted to a warm spring in the Bridger Canyon (Kindschi 1994, MTNHP 2015). It is not possible to identify larvae of this riffle beetle genus to the species level; therefore, additional site visits are needed to collect adults for a definitive species determination. This study reports that the springsnails in the Bedford Spring stream channel are the dominant member of this benthic assemblage and virtually cover the available substrate with live or dead shells. Although the Bedford springsnail population is robust in terms of numbers of individuals compared to other estimated springsnail populations (Martinez and Thome 2006, Martinez 2009, Hershler et al. 2014), it could be extirpated with one catastrophic upstream event in this small catchment area. It may be imperative to initiate a conservation easement or implement other riparian protective measures with the landowners to protect the habitat of this unique endemic species.

I thank William H. Clark (Orma J. Smith Museum of Natural History, College of Idaho, Caldwell, ID) for vouchering specimens at the invertebrate collections. Jane
Horton (MTFWP) identified the understory plants at the study site. Editorial review and comments from anonymous reviewers greatly improved this manuscript.

\section{Literature Cited}

Frest, T.J., And E.J. Johannes. 1995. Interior Columbia Basin Mollusk Species of Special Concern. Final Report to Interior Columbia Basin Ecosystem Management Project. Deixis Consultants, Seattle, WA. $\mathrm{xi}+362 \mathrm{pp}$.

Hershler, R. 1994. A review of the North American freshwater snail genus Pyrgulopsis (Hydrobiidae). Smithsonian Contributions to Zoology 554 .

Hershler, R., and D.L. Gustafson. 2001. First record for springsnails (Mollusca: Hydrobiidae: Pyrgulopsis) from the northern Rocky Mountains. Proceedings of the Biological Society of Washington 114: 297-308.

Hershler, R., H.-P. Liu, and C. Bradford. 2013. Systematics of a widely distributed western North American springsnail, Pyrgulopsis micrococcus (Caenogastropoda, Hydrobiidae), with descriptions of three new congeners. ZooKeys 330:27-52.

Hershler, R., H.-P. Liu, and D.L. Gustafson. 2008. A second species of Pyrgulopsis (Hydrobiidae) from the Missouri River basin, with molecular evidence supporting faunal origin through Pliocene stream capture across the northern Continental Divide. Journal of Molluscan Studies 74:403-413.

Hershler, R., H.-P. LiU, and J. Howard. 2014. Springsnails: a new conservation focus in Western North America. BioScience 64:693-700.

Kabat, A.R., and R. Hershler. 1993. The Prosobranch snail family Hydrobiidae (Gastropoda: Rissooidea): review of classification and supraspecific taxa. Smithsonian Contributions to Zoology 547:1-94.

Kindschi, G. 1994. Draft beetle conservation management plan and update on recent activities. FWS Fish Technology Center, Bozeman, MT. 10 pp.

Malcom, J., W.R. RadKe, and B.K. Lang. 2005. Habitat associations of the San Bernardino springsnail, Pyrgulopsis bernardina (Hydrobiidae). Journal of Freshwater Ecology 20:71-77.

Martinez, M.A. 2009. Population size estimates for Pyrgulopsis trivialis (Hydrobiidae), an imperiled aquatic snail from east-central Arizona. Journal of the Arizona-Nevada Academy of Science 41: $30-33$.

Martinez, M., AND D.M. Thome. 2006. Habitat usage by the Page springsnail, Pyrgulopsis morrisoni (Gastropoda: Hydrobiidae), from central Arizona. Veliger 18:8-16.

MladenKa, G.C., and G. Wayne Minshall. 2001. Variation in the life history and abundance of three populations of Bruneau hot springsnails (Pyrgulopsis bruneauensis). Western North American Naturalist 61:204-212.

[MDEQ] Montana Department of Environmental QUALITY. 2012. Sample collection, sorting, and taxonomic identification of benthic macroinvertebrates standard operating procedure. Montana Department of Environmental Quality, Helena, MT. WQPBWQM-012 
[MTnhP] Montana Natural Heritage Program. 2015. Montana Natural Heritage - SOC: Animals [web application]. Helena, MT. http://mtnhp.org/Species OfConcern

NatureServe. 2015. NatureServe Explorer: an online encyclopedia of life, version 7.0 [web application]. NatureServe, Arlington, VA. http://www.natureserve .org/explorer

Tsai, Y.J.J., K. Maloney, and A.E. Arnold. 2007. Biotic and abiotic factors influencing the distribution of the Huachuca springsnail (Pyrgulopsis thompsoni). Journal of Freshwater Ecology 22:213-218.
[USFWS] United States Fish and Wildlife Service. 2003. Candidate assessment and listing priority assignment form: Pyrgulopsis trivialis. U.S. Fish and Wildlife Service, Arizona Ecological Service Office, Phoenix, AZ. 8 pp.

Wolman, M.G. 1954. A method of sampling coarse riverbed material. EOS, Transactions American Geophysical Union 35:951-956.

Received 1 February 2016 Accepted 19 July 2016 